\title{
PERILAKU DAN MOTIF PADA GURU DALAM MENONTON TELEVISI DI DUA TIPOLOGI DESA DI KABUPATEN BOGOR
}

\author{
Imas Masriah*) \\ Email : imasriah68@gmail.com
}

\begin{abstract}
ABSTRAK
PERILAKU DAN MOTIF PADA GURU DALAM MENONTON TELEVISI DI DUA TIPOLOGI DESA DI KABUPATEN BOGOR. Penelitian ini bertujuan untuk mengidentifikasi jenis acara yang sering ditonton guru, mengidentitikasi motif menonton televisi guru dan menganalisis perbedaan motif menonton siaran televisi antara guru di desa urban dengan guru di desa rural. Populasi penelitian ini adalah guru di Kabupaten Bogor pada empat desa yang dipilih secara random purposive. Responden diambil secara acak, jumlah seluruh responden 160 guru. Metode penelitian ini adalah deskriptif yang bersifat eksploratif. Hasil penelitian menunjukkan sebagai berikut: Pertama, Kebiasaan menonton televisi di desa urban dan desa rural tidak menunjukkan perbedaan yang berarti. Ada tiga acara yang paling disukai responden, yaitu film/sinetron $78(48,75)$, berita $33(20,62)$ dan aneka kuis $9(18,13)$. namun di desa urban berturut-turut yang disukai yaitu film/sinetron $36(45)$, aneka kuis $18(22,50)$, dan berita $13(6,25)$, sedangkan didesa rural : fll m sinetron $42(52,5)$, berita $20(25,00)$ dan aneka kuis $11(13,75)$. Responden di desa urban lebih menyukai acara-acara hiburan, sedangkan di desa rural selain menyukai acara hiburan, juga menyukai aca ra berita Kedua, motif menonton televisi yang utama adalah : hiburan $52(64,38)$ dan memperoleh informasi $27(33,75)$. Motif hiburan dan informasi yang paling banyak diungkapkan responden: di desa urban sebanyak $49(61,25)$ dan 28 $(35,00)$, untuk rural sebanyak 54(67,50) dan $26(32,50)$. Ketiga, Hasil menunjukkan bahwa tidak ada perbedaan motif dalam menonton televisi, baik di desa urban maupun di desa rural. Pemanfaatan media komunikasi massa yang tersedia relative tidak jauh berbeda dengan guru di desa rural. Guru di desa urban motif informasinya cenderung untuk pemenuhan kebutuhan akan berita, sementara di desa rural untuk memenuhi kebutuhan pengetahuan yang bersifat praktis.
\end{abstract}

Kata Kunci : Perilaku, Motif, and Menonton

\begin{abstract}
BEHAVIOR AND MOTIVE TO TEACHERS IN WATCHING TELEVISION IN TWO VILLAGE TYPOLOGY IN BOGOR REGENCY. This study aims to identify the types of events that teachers often watch, to identify the motives of watching television teachers and to analyze the differences in the motives of watching television broadcasts between teachers in urban villages and teachers in rural villages. The population of this study were teachers in Bogor Regency in four villages selected by random purposive. Respondents were drawn at random, the total of 160 teachers. This research method is descriptive that is explorative. The results showed as follows: First, the habit of watching television in urban and rural villages showed no significant difference. There are three shows that most liked by the respondents, namely film / sinetron 78 (48,75), news 33 $(20,62)$ and various quiz $9(18,13)$. but in the preferred urban villages of 36 (45), $36(45), 18$ (22.50), and 13 (6.25), while rural: 42 sinetrons (52.5), news $20(25,00)$ and various quiz 11 $(13,75)$. Respondents in urban villages prefer entertainment events, whereas in rural villages besides enjoying entertainment, also like news events Secondly, the main television viewing motifs are: entertainment $52(64,38)$ and information $27(33,75)$. The most informed and informed motives were respondents: in urban villages $49(61,25)$ and $28(35,00)$, for rural $54(67,50)$ and $26(32,50)$. Third, the results show that there is no difference in motif in watching television, both in urban and rural villages. Utilization of mass communication media available relative not much different from teacher in rural village. Teachers in urban villages informative motives tend to fulfill the need for news, while in rural villages to meet practical knowledge needs.
\end{abstract}

Keywords: Behavior, Motive, and Watch

*) Dosen Program Studi Magister Manajemen - UNPAM 


\section{PENDAHULUAN}

Dewasa ini media masa televisi telah menjadi bagian dari kehidupan masyarakat termasuk guru, terutama di daerah urban. Guru bagian dari masyarakat di desa urban umumnya dicirikan dengan pemilikan televisi yang cukup tinggi (di atas 50\%), lebih intensif memanfaatkan televisi sebagai media komunikasi massa dengan frekuensi menonton televisi meneapai hampir 6(enam) kali seminggu dan waktu yang dicurahkan sekitar tiga jam perhari (Hadiyanto, 1998). Namun belum ada data yang mengungkapkan motif-motif apa saja yamg mendorong mereka menonton siaran televisi, sebagaimana dikemukakan Ehandler (1994), program televisi yang sama bisa memberikan pemuasan kebutuhan yang berbeda pada setiap individu yang berbeda.

Studi tentang preferensi terhadap acara dan motif-motif penggunaan media informasi dan pengetahuan untuk menjelaskan mengapa pesan-pesan komunikasi yang disiarkan televisi memberikan efck yang berbeda pada setiap orang. Penelitian serupa ini sesungguhnya sangat penting untuk memahami proses komunikasi massa ditinjau dari perspektif active audien (Blumler \& Katz, 1974). Berdasarkan informasi inilah diharapkan televis dapat memberikan kontribusi sebagai media pembangunan.

Penelitian difokuskan kepada komunitas pendidik / guru pada tipologi desa berbeda dengan maksud untuk memberikan gambaran yang bisa mewakili, baik masyarakat desa yang secara sosio ekonomis dan kultural berada dalam tahap transisi perubahan.

Penelitian ini bertujuan : (1) mengidentifikasi jenis-jenis acara apa saja yang sering ditonton guru pada desa urban dan desa rural. (2) mengidentitikasi motif-motif menonton televisi guru balk yang di desa urban maupun desa rural, dan (3) menganalisis perbedaan motif menonton siaran televisi antara guru di desa nrban dengan guru di desa rural.

\section{MATERI DAN METODE}

\section{A. Populasi dan Sampel}

Populasi penelitian ini adalah pendidik/guru di daerah kelompok empat desa yang dipilih secara random purposif masing-masing dua desa mewakili desa urban dan dua desa mewakili desa rural. Selanjutnya sampel guru respoden diambil secara acak, masing-masing 40 guru pada setiap desa, sehingga jumlah seluruh responden adalah 160 guru.

\section{B. Desain}

Penelitian ini di desain sebagai suatu survei deskriptif yang bersifat eksploratif di 4 (empat) desa di Kabupaten Bogor (Rakhmat, 1989; Wimmer \& Dominick, 1987). 


\section{Lokasi dan Waktu}

Lokasi penelitian adalah Desa Tamansari dan Desa Sukajadi yang mewakili desa urban, sementara yang mewakili desa rural adalah Desa Karacak dan Desa Sukadamai. Pengumpulan data dilakukan selama satu bulan yaitu Agustus 2017.

\section{Data dan Instrumen}

Data yang dikumpulkan meliputi karakterisitik demografi responden, perilaku dan motif-motif menonton siaran televisi. Pengumpulan data dilakukan dengan teknik wawancara mengunakan instrumen bcrupa kuesioner.

\section{E. Analisa Data}

Analisa data terutama mengunakan analisis deskriptif, sementara untuk mcnguji apakah hubungan antara tipologi desa dengan motif penggunaan televisi digunakan uji statistik chi kuadrat.

\section{HASIL DAN PEMBAHASAN}

\section{A. Karakteristik Responden}

Hasil penelian menunjukan bahwa para guru responden di desa urban maupun rural di Kabupaten Bogor, umumnya sudah dewasa dengan umur-umur rata-rata 40,69 tahun. Meskipun demikian rata-rata umur di desa urban masih lebih tinggi (42,15 tahun) dibandingkan di desa rural (39,24 tahun). Guru responden di desa urban, scbagian besar wanita $(78,7596)$, demikian juga di desa rural $(70,0096)$. Data tersebut menunjukan partisipasi wanita sebagai guru di desa urban lebih tinggi dibandingkan di desa rural.

\section{B. Pemilikan Media Massa Elektronik}

Pemilikan media komunikasi massa, di era informasi mcrupakan indikator keterbukaan suatu masyarakat. Oleh karena itu, pcnelitian ini berusaha mengungkap kandistribusi kcpemilikan media komunikasi massa, terutama elektronik, sebagai indikator tingkat keterbukaan masyarakat terhadap media komunikasi massa. Gambaran tentang kepemilikan media komunikasi massa secara ringkas disajikan pada tabel 1.

Tabel 1. : Distribusi Responden Berdasarkan Pemilikan Media Komunikasi Massa (\%)

\begin{tabular}{|c|c|c|}
\hline Jenis Media Massa & Desa Urban & Desa Rural \\
\hline Tidak Punya & 2,50 & 15,00 \\
\hline Hanya Radio & 10,00 & 11,25 \\
\hline Hanya Televisi & 32.50 & 16,25 \\
\hline Radio+Televisi & 55,00 & 56,25 \\
\hline
\end{tabular}

Data tersebut menunjukkan, persentase responden yang tidak memiliki media massa elektronik di desa urban lebih rendah dbandingkan di desa rural, dan persentase tersebut jauh lebih kecil dibandingkan responden yang memiliki media massa elektronik. 
Sementara pemilik radio relatif lebih tinggi di desa rural, dun persentase tersebut jauh lebih kecil dibandingkan responden yang memiliki media massa eleknonik. Sementara pemilikan radio relative lebih tinggi di desa rural, sebaliknya yang hanya memiliki televisi lebih banyak di desa urban. Data tersebut juga memberikan gambaran bahwa sekalipun televisi telah menjadi media massa elektronik yang populer, baik di desa urban maupun desa rural, masih banyak responden yang mempertahankan kepemilikan radio. karena radio memiliki beberapa keunggulan dibandingkan dengan televisi, antara lain lebih praktis penggunaannya dan lebih personal.

\section{Perilaku MenontonTelevisi}

Berikut ini akan dibahas beberapa aspek yang terkait dengan perilaku menonton elevisi untuk memberikan gambaran yang lebih lengkap, sebelum mengungkapkan dan menganalisis aspek motif tersebut. Beberapa aspek yang dibahas mcliputi antara lain ; (i) frekuensi menonton, (ii) kebiasaan menonton, (iii) tempat menonton, (iv) waktu yang dicurahkan untuk menonton, dan ( $v$ ) jenis acara yang paling sering ditonton.

Seluruh responden di desa urban menyatakan menonton televisi setiap hari, scmentara di desa rural banyaknya responden yang menonton televisi setiap hari hanya 56 responden (7096), Jumlah responden yang mcnonton tclevisi antara 4-6 kali perminggu mencapai 8,196 , sedangkan sisanya berkisar antara1sampai dengan 3 kali perminggu (6,86\%).

Sehagian besar guru menonton televisi bersama keluarga $(8,5 \%$ di desa urban dan $71,25 \%$ di dcsa rural). Hanya sebagian kecil yang memiliki kebiasaan menonton televisi sendiri, apalagi dengan tetangga atau saudara. Kebiasaan menonton televisi sendirian banyak ditemui pada responden wanita yang menonton televisi pada sore hari dan malam hari, ketika anak tidak berada di rumah. Bagi responden laki-laki, umumnya menonton televisi dilakukan sendiri pada malam hari, distribusi responden menurut kebiasaan menonton televisi selengkapnya disajikan pada Tabel 2.

Tabel 2. : Persentase responden menurut kebiasaan menonton televisi $\%$ ).

\begin{tabular}{|l|c|c|c|}
\hline Kebiasaan Menonton & Desa Urban & Desa Rural & Seluruh Responden \\
\hline Sendiri & 0,50 & 11,25 & 13,75 \\
\hline Dengan Keluarga & 85,00 & 7125 & 76,25 \\
\hline Dengan tetangga/ & 13,75 & 17,50 & 15,62 \\
\hline Saudara & & & \\
\hline
\end{tabular}

Gambaran di atas sejalan dengan tempat menonton televisi, yang menunjukan sebagian besar responden, baik di desa urban maupun di desa rural dilakukan di rumah sendiri masing-masing sebanyak $82,50 \%$ dan $7,0 \%$. Sementara yang menonton di rumah tetangga atau saudara di desa urban dan desa rural masing-masing $17,50 \%$ dan $30 \%$. Hal ini menunjukkan pada responden di desa rural masih lebih tinggi persentasinya yang menonton di rumah tetangga, sebagai akibat masih lebih kecilnya pemilikan televisi dibandingkan responden di desa urban. 
Responden di desa rural, waktu siang hari lebih banyak dihabiskan untuk tugastugas rumah tangga, bekerja dan berinteraksi dengan sesama tetangga. llustrasi ini mengindikasikan bahwa di desa rural masih cukup kuat interaksi sosial antar warga masyarakat, sedangkan di desa urban tampaknya responden lebih suka menghabiskan waktu siangnya di rumah sendiri, sehingga mengurangi kesempatan untuk berinteraksi dengan sesama tetangga.

Lamanya waktu yang dicurahkan untuk menonton televisi memberikan gambaran, apakah media massa tersebut merupakan media pilihan responden untuk memperoleh informasi dan tujuan-tujuan komunikasi lainya. Rata-rata waktu yang dituangkan untuk menonton televisi pada waktu yang berbeda secara ringkas disajikan pada Tabel 3.

Tabel 3.: Rata-rata waktu yang diluangkan responden untuk menonton televisi (Garn)

\begin{tabular}{|c|c|c|c|}
\hline Waktu Menonton & Desa Urban & Desa Rural & Seluruh Responden \\
\hline Pagi & 0,22 & 0,21 & 0,21 \\
\hline Siang & 4,08 & 0,32 & 2,20 \\
\hline Sore & 0,31 & 0,16 & 0,39 \\
\hline Malam & 85,00 & 71,25 & 76,25 \\
\hline Total & 13,75 & 17,50 & 15,62 \\
\hline
\end{tabular}

Pengertian waktu yang diluangkan dalam peneitian bermakna bahwa kegiatan menonton te1evisi bisa dianggap sebagai aktivitas primer maupun aktivitas sekunder (Comstok,al., 1978). Data tersebut mengindikasikan di desa urban terdapat perbedaan pola menonton televisi. Sementara hasil penelitian ini menunjukkan, waktu yang lebih banyak diluangkan untuk menonton televisi ialah pada siang hari. Keadaan ini dimungkinkan oleh dua penyebab. Pertama, hampir seluruh stasiun televisi yang ada saat ini menyiarkan program-program acaranya pada siang hari. Kedua kesempatan responden yang sebagian besar wanita/ibu rumah tangga yang lebih banyak menonton pada siang hari ketika udah tidak lagi disibukkan demgan aktivitas rutin lainnya. Sementara bagi responden di desa rural malam hari masih merupakan pilihan waktu yang paling tepat untuk menonton televisi.

Berdasarkan waktu yang dicurahkan terlihat bahwa responden di desa urban jauh lebih intensif menonton televisi, terbukti dengan curahan waktu yang lebih banyak untuk menonton televisi dibandingkan dengan responden di desa rural. Pilihan siaran televisi yang ditonton disamping popularitas stasiun televisi bersangkutan sangat ditentukan pula oleh yang menentukan siaran televisi yang ditonton. Hasil penelitian ini menunjukan, baik di desa urban maupun di desa rural pihak yang paling banyak menentukan siaran televisi yang ditonton terutama pada pagi hari, siang hari, dan sore hari oleh anak masing-masing sebesar 53,749 dan 41,2096. Di desa urban, penentu berikutnya ialah ibunya baru kemudian bapak. Sebaliknya di desa rural peranan bapak lebih dominan dibandingkan ibu. Walaupun demikian 11,2596 responden di desa urban mengaku tidak ada pihak dalam keluarga yang mendominasi siaran televisi apa yang hendak ditonton. Hal ini sama dijumpai pada sebanyak 19,5096 responden yang berada di desa rural. 


\section{Acara Televisi yang Ditonton}

Berdasarkan data yang ada jenis acara yang ditonton responden dapat dikelompokkan menjad ienam jenis acara yaitu; (i) film/sinetron, (ii) berita, (iii) music, (iv) aneka kuis, (v) olahraga, dan (vi) kesenian tradisional. Distribusi responden berdasarkan jenis acara yang paling disukai disajikan pada Tabel 4.

Tabel 4.: Distribusi responden berdasarkan jenis acara televisi yang paling disukai oleh responden (\%)

\begin{tabular}{|l|c|c|c|}
\hline \multicolumn{1}{|c|}{ Jenis Acara } & Desa Urban & Desa Rural & Seluruh Responden \\
\hline Film/sinetron & $36(45)$ & $42(52,5)$ & $78(48,75)$ \\
\hline Berita & $13(6,25)$ & $20(25,00)$ & $33(20,62)$ \\
\hline Musik & $5(6,25)$ & $3(3,75)$ & $8(5,00)$ \\
\hline Aneka kuis & $18(22,50)$ & $21(13,75)$ & $9(18,13)$ \\
\hline Olahraga & $5(6,25)$ & $3(3,15)$ & $8(5,00)$ \\
\hline Kesenian Tradisional & $1(1,25)$ & $1(1,25)$ & $2(1,25)$ \\
\hline Tidak Menjawab & $2(2,50)$ & $0(0,00)$ & $2(1,25)$ \\
\hline
\end{tabular}

Data Tabel 4 menunjukkan, acara yang paling disukai responden di desa urban berturut-turut ialah : film/sinetron, aneka kuis, dan berita. Sementara di desa rural terdiri dari :fllm/sinetron, berita, dan aneka kuis. Ilustrnsi tcrsehut mongind ikasikan bahwa responden di desa urban lebih menyukai acara-acara hiburan, sedangkan di desa rural selain acara hiburan, jumlah responden yang menyukai aca ra berita juga proporsinya cukup tinggi bahkan lebih tinggi dari responden di desa urban. Demikian pula yang menyukai acara film/sinetron di desa rural jumlahnya lebih banyak_dibandingkan di desa urban. Data tersebutt menggamharkan bahwa tidak ada perbedaan yang berarti tentang jcnis-jenis acara televisi yang disukai responden baik di desa urban maupun di desa rural. Gambaran ini memperkuat pendapat yang selama ini berkembang bahwa media massa televisi lebih banyak dimanfaatkan sebagaimana media hiburan dibandingkan dengan fungsi-fungsi komunikasi lainnya seperti sebagai media informasi dan media pendidikan. Bukti ini scbenarnya tidaklah mengherankan, karena sebagian bcsar acara di televisi juga lebih banyak bersifat hiburan. Sebagai ilustrasi, TPI yang selama ini dikenal dengan siaran televisi pendidikan. Sementara acara informasi/berita, pendidikan dan acara penunjang lainnya masing-masing porsinya $8,0 \% ; 7,76 \%$; dan 1,68\%. Gambaran yang kurang lebih sama juga bisa ditemui pada stasiun televisi lainnya. Bahkan TVRI yang merupakan satu-satunya stasiun televisi publik milik pemerintah pun, sejak statusnya menjadi persero memiliki kecenderungan mcngikuti pola siaran televisi swasta, tcrmasuk di dalamnya menyiarkan iklan yang merupakan salah satu sumber pendanaan bagi TVRI.

\section{E. Motif Menonton Televisi}

Motif-motif menonton televisi yang diidentifikasi dalam penelitian ini berperan pada asumsi model "Uses and Gratification" sebagaimana dikemukakan oleh Katz (19.74) yang diperkuat pendapat Stamm \& Bowes (1990) serta digunakan teknik "self reforting" dengan jumlah daftar motif sebagaimana dikembangkan oleh Denis Mc Quail (Chandler, 1994). 
Responden guru yang sebagian besar wanita dengan pendidikan setinkat SMU nampaknya kemampuan megungkapkan motif menonton televisi sangat terbatas. Hal ini berarti mereka umumnya belum mampu membedakan antara satu jenis motif dengan motif lainnya. Jumlah motif yang mampu diungkapkan responden hanya berkisar antara 2 (dua) sampai 6 (enam) jenis motif dari 12 (dua belas) daftar motif yang dirumuskan dan pilihannya sangat beragam. Berdasarkan fakta ini kemudian disusun kembali daftar motif yang menjadi pilihan responden (Tabel 5).

Tabel 5.: Distribusi responden berdasarkan motif utama menonton televisi

\begin{tabular}{|c|c|c|}
\hline \multirow{2}{*}{$\begin{array}{c}\text { Pernyataan } \\
\text { motif menonton televisi }\end{array}$} & \multicolumn{2}{|c|}{ Jumlah Responden } \\
\hline & Desa Urban & Desa Rural \\
\hline Motif informasi: & 28 & 26 \\
\hline $\begin{array}{l}\text { a. Saya menonton televisi untuk } \\
\text { mengetahui peristiwa aktual yang } \\
\text { terjadi di masyarakat }\end{array}$ & 27 & 18 \\
\hline $\begin{array}{l}\text { b. Saya menonton televisi untuk } \\
\text { menambah Pengetahuan atau } \\
\text { keterampilan seperti Agama, } \\
\text { Pendidikan, Kesehatan, Memasak, } \\
\text { model dan sebagainya. }\end{array}$ & 1 & 4 \\
\hline $\begin{array}{l}\text { c. Saya menonton televisi karena } \\
\text { banyak memperoleh pelajaran } \\
\text { berharga }\end{array}$ & 0 & 4 \\
\hline Motif identitas-personal : & 3 & 0 \\
\hline $\begin{array}{l}\text { a. Televisi banyak memberikan } \\
\text { perilaku yang bisa ditiru }\end{array}$ & 3 & 0 \\
\hline Motif hiburan: & 49 & 54 \\
\hline $\begin{array}{l}\text { a. Untuk melupakan sejenak masalah } \\
\text { keluarga yang sedang dihadapi }\end{array}$ & 0 & 2 \\
\hline $\begin{array}{l}\text { b. Untuk melepaskan ketegangan } \\
\text { setelah seharian bekerja }\end{array}$ & 2 & 6 \\
\hline $\begin{array}{l}\text { c. Untuk mengisi waktu senggang } \\
\text { sambil beristirahat }\end{array}$ & 3 & 6 \\
\hline $\begin{array}{l}\text { d. Untuk rnembuat perasaan senang } \\
\text { dan gembira }\end{array}$ & 44 & 40 \\
\hline
\end{tabular}

Berdasarkan data tersebut jelas sekali tergambar bahwa motif hiburan dan informasi paling banyak diungkapkan responden, baik di desa urban maupun rural. Tampaknya karakter televisi yang diterima sebagai media penghibur (Comstoketal,1978) semakin memperoleh justifikasi. Motif hiburan yang dominan jalah untuk membuat perasaan senang dan gembira. Damping ada pula sebagian kecll di desa rural yang menonton televisi untuk sejenak melupakan masalah keluarga yang sedang dihadapi. Rendahnya jumlah responden yang menganggap 
menonton televisi sebagai sarana melepaskan ketegangan dan mengisi waktu senggang menunjukan, televisi lebih menonjol sebagai sarana hiburan. Motif yang berkaitan dengan identitas personal dan integrasi/interaksi sosial hanya diungkapkan oleh sebagian kecil responden. Sebagai ilustrasi responden yang menyatakan bahwa menonton televisi karena banyak contoh perilaku yang bisa ditiru sebagaimana motivasi dari identitas personal hanya dinyatakan oleh 3 (tiga) responden di desa urban, sementara itu tidak satupun responden yang menyatakan bahwa motif utama menonton televisi ialah sebagai sarana untuk mempererat solidaritas dan interaksi sosial diantara sesama warga.

Berdasarkan data ini dan hasil uji chi kuadrat menunjukkan bahwa tidak ada perbedaan motif dalam menonton televisi, baik di desa urban, maupun di desa rural $(\rho>0,05)$. Hal ini disebabkan, meskipun guru di desa urban memiliki aksesibilitas yang lebih mudah terhadap sumber-surnber informasi namun pemanfaatan media komunikasi massa yang tersedia relatif tidak berbeda jauh dengan guru di desa rural.

Walaupun dernkian, ada kecenderungan guru di desa urban motif informasinya ialah pemenuhan kebutuhan akan berita, sementara di desa rural untuk memenuhi kebutuhan pengetahuan yang bersifat praktis.

\section{KESIMPULAN}

Kebiasaan menonton televisi antara guru di desa urban dan desa rural tidak menunjukkan perbedaan yang berarti, kecuali dalam waktu yang dicurahkan menonton. Meskipun demikian, lama menonton televisi tidak berpengaruh terhadap jenis acara yang disukai responden baik di desa urban maupun di desa rural. Ada tiga acara yang paling disukai responden, yaitu film/sinetron, berita dan aneka kuis.

Motif-motif menonton televisi yang utama adalah : hiburan dan memperoleh informasi. Tidak ada perbedaan motif menonton televisi antara guru di desa urban dengan guru di desa rural.

\section{DAFTA R PUSTAKA}

Blumler, J.G\&E.Katz.1974.The Uses of Mass Communications: Current Perspective Son Gratifications Research. Sage Publications, Beverly Hills. California.

Chandler D. 1994. 'Why do People watch television http://www.aber.ac.uk/ media/ffunction/msc.html. (10 Juni 1999).

Comstock, G., S. Chafee, N. Katzman, M. Mc Combs, \& D. Robert. 1978. Television and Human Behavior. Colombia University Press, New York.

Harahap, A.S. 2001. Hubungan karakteristik guru dengan perilaku menonton dan persepsinya terhadap program hiburanTPI : Kasus guru SMU Negcri Kodya Depok. Thesis Magister Sains, Program Pascasarjana IPB, Bogor. 
Katz, E., J. G. Blumbe:r, \& M.Gurevich. 1974. "Utiliation of Mass Communication by individuual", The Uses of Communication a Current Perspective son Gratifications. Research. J.G .Blumber \& E. Katz (Eds). Suge Publications, Beverly Hills. California.

Rakhmat, J. 1989. Metode Penelitian Komunikasi. Penerbit Remadja Karya CV, Bandung.

Stann, K.R. \& J.E. Bowen. 1990. 'The Mass Communication Process. A Bihavioral and Social Perpective. Kendall / Hant Publishing Company, Dubuque, lowa.

Wimmer,R.D.\&J.R.Dominick.1987. Mass Media Research. An Introduction 2nd ed. Wadsworth Publishing Company, Belmont, Califomia. 